\title{
MACROPHYTES IN THE LITTORAL OF LAKE ARAKHLEY IN DIFFERENT STATES OF WATER REGIME
}

\author{
ALEXEY P. KUKLIN, BALZHIT B. BAZAROVA
}

Institute of Natural Resources, Ecology, and Cryology; Siberian Branch of RAS, 16A Nedorezov Street, 672014 Chita, Russia; e-mail: kap0@mail.ru

\begin{abstract}
Kuklin A.P., Bazarova B.B.: Macrophytes in the littoral of Lake Arakhley in different states of water regime. Ekológia (Bratislava), Vol. 38, No. 3, p. 225-239, 2019.

The study of aquatic vegetation in the littoral of the dimictic water bodies of taiga is of particular interest in case of long-term observations carried out under conditions of climate fluctuations. During the low-water period, drying of the littoral with a decrease in the water level leads to the changes in phytomass of macrophytes, as well as in the composition of species and their distribution by depth. The area of littoral covered with ice in winter is also large in the low-water period; it affects the growth of perennial plants. When the water level decreases, the sand beach replaces the sand and pebble beach; it leads to the disappearance of epilithon and the predominance of rooting plants. The features of vegetation were determined for each period of water content. The low-water period is characterised mostly by grass-type vegetation; the high-water period is characterised by vegetation of mixed type.
\end{abstract}

Key words: littoral, aquatic vegetation, macroscopic algae, climatic cycles, Lake Arakhley.

\section{Introduction}

Climatic changes in the northern latitudes are characterised by continuing warming, whose rate is 2.5 times higher than that global warming (RosHydroMet, 2014). In Transbaikal region, the area of water bodies is decreasing, shallow waters are drying and ecotonal littoral ecosystems are adapting to new climatic conditions. The study of ecotones in the past decade is in the field of attention of UNESCO (Raspopov et al., 1998). Environmental factors such as storms or significant changes in water temperature have very strong influence on biological communities of littoral zones. One of the most influential factors is cyclical inter-annual fluctuations of the water level, which lead either to the drying of large areas of the littoral and destruction or the transformation of the hydrobiont complexes or to the flooding of the coastal areas with rising water and formation of new communities (Kurashov, 2011). Longterm observations of the state of ecosystems provide the most valuable data for the prediction of the effects of climate change (Sirakov, Slavcheva-Sirakova, 2015).

The littoral zone is characterised by the greatest biodiversity and bioproductivity in comparison to other parts of lakes. Biological and biochemical processes have the highest rates there. This zone is an exclusive area of distribution of higher aquatic plants; it extends from 
the shoreline to the lower boundary of the growth of macrophytes. Macrophytes, along with bottom sediments and water mass, are the main environment-forming elements of the littoral ecosystem. Long-term series of observations were carried out on the Narochansky Lakes (Mikheeva, Lukyanova, 2006), Lake Ladoga (Kurashov, 2011), Lake Chany (Bykova, 2013), lakes of Europe (Scheffer, 1997; Zębek, 2014), lakes of Asia (Atapaththu et al., 2017) and others. These studies characterise the climatic changes in conditions of temperate climate. However, there are only few works related to long-term series of observations, studying ecosystems of water bodies in conditions of extremely continental climate. Therefore, there is an urgent need to study the aquatic vegetation of water bodies in the areas of extremely continental climate.

Lake Arakhley is one of the large dimictic water bodies located in taiga of the Eastern Transbaikal region; it belongs to the Baikal basin. Arakhley is the largest lake in the IvanoArakhley system of lakes located in the southern part of the Vitim plateau. According to modern views, Lake Arakhley is the remainder of a large periglacial water body, which existed in the Transbaikal region at the time of maximum of the Samarovsky glaciation and connected Baikal Lake with the Amur River basin (Kuklin, Enikeev, 2017). The inter-annual fluctuations in the level of water surface of Lake Arakhley can reach $3 \mathrm{~m}$ in height. According to this value, Lake Arakhley takes an intermediate position between northern water bodies of the Transbaikal region characterised by low fluctuations of water level (Talovskaya, 1977) and the steppe water bodies characterised by pronounced fluctuations, which can reach $7 \mathrm{~m}$ in height (Ivanov, 1977). In the 1960-s, the theory about the cyclic development of the lake ecosystems in conditions of extremely continental climate of the Transbaikal region emerged (Shishkin, 1973). At the same time, stationary studies were started on Lake Arakhley, which made it possible to trace the dependence of the ecosystem of the lake on the dynamics of climatic parameters, in particular, the amount of precipitations and, consequently, on fluctuations in the water level (Bazarova, Itigilova, 2006). The information was summarised in monographs 'Biological productivity of Lake Arakhley (Transbaikalia)' (Bekman, Gorlachev, 1981) and 'The Ivano-Arakhley lakes at the turn of the century (state and dynamics)' (Obyazov, 2013).

Preliminary data on vegetation of the Ivano-Arakhley lakes were obtained in 1931 (Kozhov, 1950). In the 1960-s, Vladimirova and Dulepova carried out hydrobotanical studies of these lakes (Vladimirova, Dulepova, 1966; Vladimirova, 1970a, b). The annual production of macrophytes of Lake Arakhley was calculated for the first time in 1967 (Bondareva, 1974). In 1974-1976, geobotanical studies were carried out on lakes Arakhley and Shakshinskoe; the role of macrophytes in the creation of primary production of these lakes was determined (Zolotareva, 1981). In 1998, the study of macroscopic filamentous algae in the littoral of the lake was started.

The aim of the present work is to study the vegetation of the littoral of Lake Arakhley in different periods corresponding to different states of water regimes in order to understand the changes occurring in the ecosystems of dimictic continental water bodies under climate fluctuations. The research tasks included the establishment of environmental factors influencing vegetation in the littoral after the change in the water level and the registration of changes in the floristic composition and distribution of plant communities in the littoral in the high-water and low-water periods. 


\section{Material and methods}

The article is based on the data obtained by the authors in the period from 1998 to 2017 in the course of stationary observations of the littoral of Lake Arakhley near Preobrazhenka village (Fig. 1). To characterise the littoral, the authors collected data on morphological structure, size and nature of the distribution of soil as well as on the chemical composition of water and the changes in depth, transparency and temperature. To characterise the macrophytes, more than 500 descriptions were given.

To construct a morphometric profile, the authors performed levelling on the drained part of the littoral of the lake near Preobrazhenka village (Fig. 2). The underwater part of the littoral was studied using an echo sounder HDS 5 Gen 2 with a beam of $50 / 200 \mathrm{kHz}\left(35^{\circ}\right)$. At shallow depths, the bandwidth, whose data were compiled to calculate the bottom line, was small, which made it possible to use an echo sounder for terrain mapping. The authors applied Surfer 13 and DrDept 4.4 software for processing the obtained data.

As the connection between pieces of the sand samples was weak, the authors applied the sieve method (GOST sieve 6613-6673 mm) to study fractional composition of the soil. Sieve analysis is applicable for materials with particle sizes of 10-0.04 mm. For the samples that had high content of organic residues or the samples that lose more than $90 \%$ of their weight during drying (collected on depth of 2-6 m), granulometric composition was not analysed.

The hydrochemical samples were collected simultaneously with samples of macrophytes. At the same time, the authors measured the physicochemical parameters of water $(\mathrm{pH}$, mineralisation, oxygen, water temperature) by AquaReader, a multi-parameter instrument for monitoring quality of water. The transparency of the water was measured using white Secchi disk. Hydrochemical analysis of the water samples was carried out by the method of atomic absorption, photometry and titrimetry in accordance with GOST 4389-72, 4192-82,3351-74, Federal Environmental Normative Document (PNDF) 14.1:2:4.138-98, 14.1:2:4.139-98 and Scientific Council on Analytical Methods of Research (NSAM) 335-g.

According to Raspopov (1975), macrophytes are macroscopic plant organisms regardless of their systematic position, which does not require the use of optical instruments with high magnification to establish their genus (in some cases, their species). Modern studies of macrophytes in the littoral of Lake Arakhley were conducted from 1998 to 2017 at 5-7 stations in the period of open water, according to the depth of growth of plants, by applying the methods widely used in such studies (Kachaeva, 1974; Katanskaya, 1981).

To determine the phytomass of macrophytes at the depths of up to $1 \mathrm{~m}$, the cuts were made using a standard counting frame with an area of $0.25 \mathrm{~m}^{2}$. At the depths of more than $1 \mathrm{~m}$, an instrument for counting gammarids was used with a capture area of $0.5 \mathrm{~m}^{2}$ (Shapovalova, Vologdin, 1973). To count charophytes, the Petersen bottom grab was used with a capture area of $0.025 \mathrm{~m}^{2}$. The sampling cuts were made on all profiles at depths of 1.0, 2.0, 3.0, 4.0, 5.0 and $6.0 \mathrm{~m}$. At these depths, rectangular platforms with a length of 10 $m$ were placed; the width of the sites depended on the outline boundaries of the communities. On these sites, 3-5 cuts were selected at a distance of at least $5 \mathrm{~m}$ from each other. The species collected in each cut were separately sorted and weighed in moist and air-dry state. To obtain an absolute dry weight, a weighed portion of one plant species (three replicates) was dried in an oven at $105^{\circ} \mathrm{C}$ for $4-6$ hours.

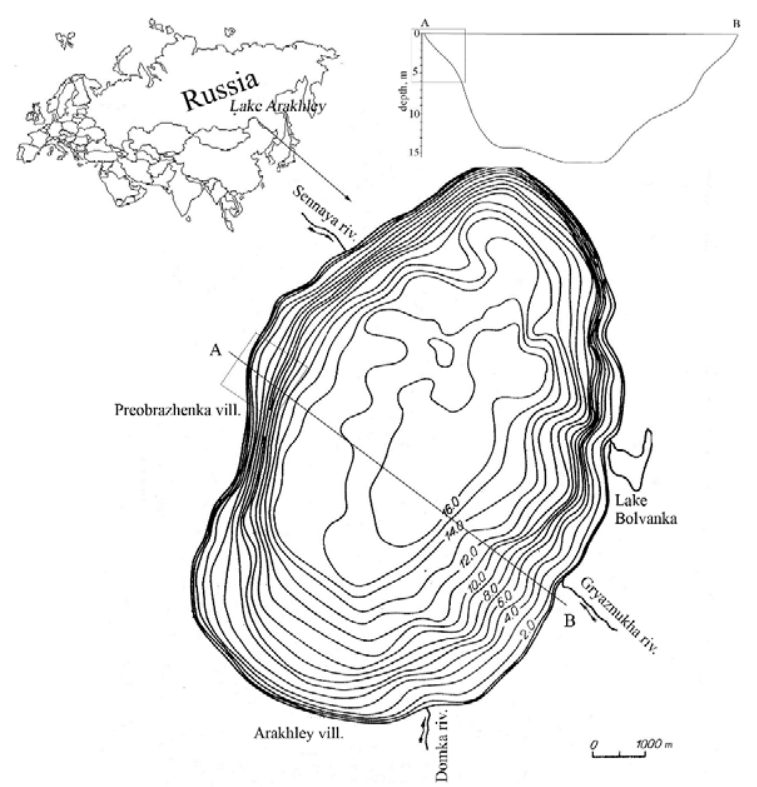

Fig. 1. Locations of sites that were used for studying the littoral of Lake Arakhley. 
a)

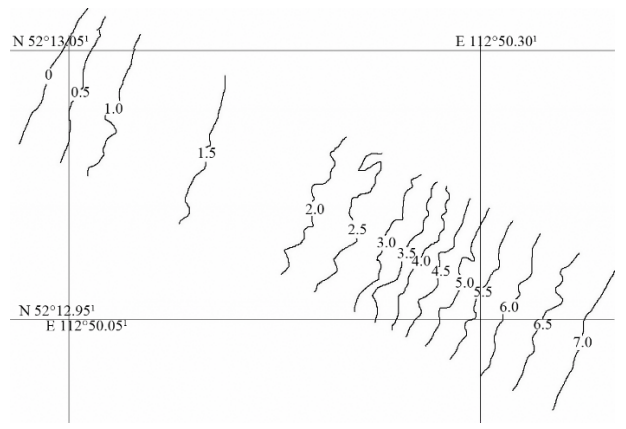

c)

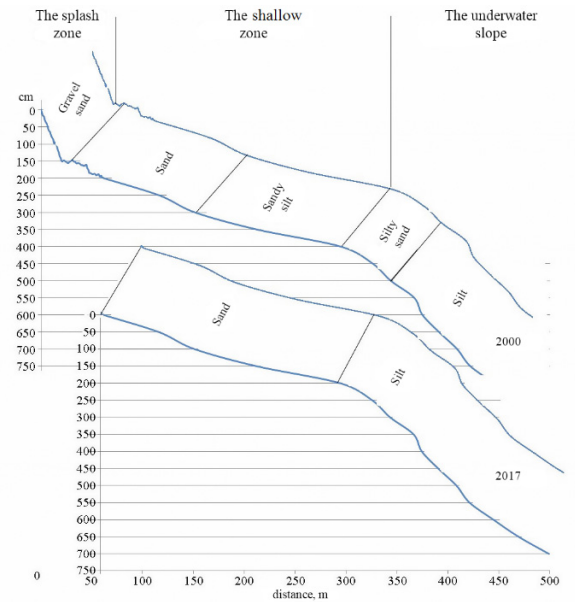

b)

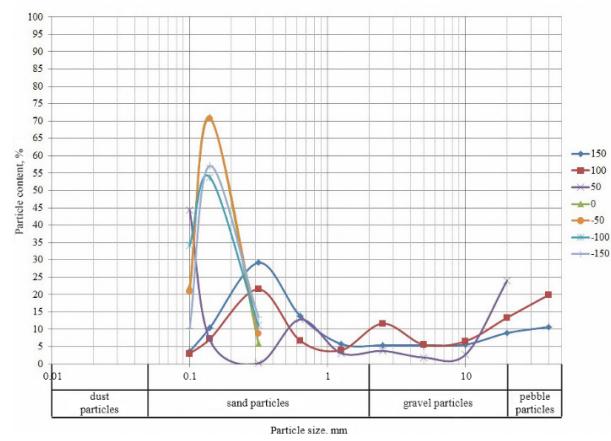

d)

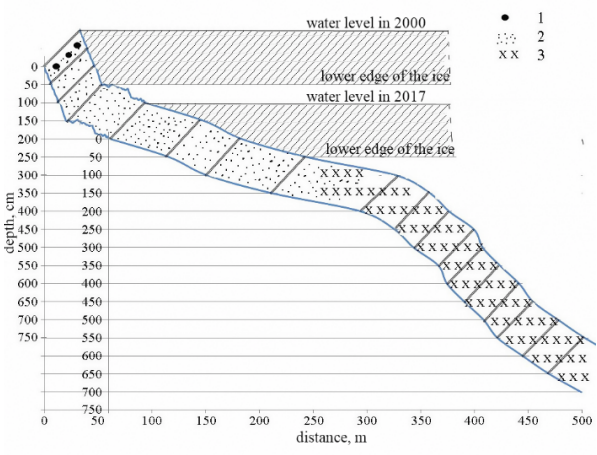

Fig. 2. Morphological structure and distribution of soils of the littoral of Lake Arakhley near Preobrazhenka village: (a) depth distribution as of 2017; (b) granulometric composition of bottom sediments; (c) distribution of various types of soils (according to Matafonov et al., 2006); (d) position of ice during the winter period. The numbers designate the following: (1) stone; (2) sand; (3) silt.

The authors selected and processed 427 cuts during the study. Macroscopic algae were collected by washing them from the substrates (pebbles, water vegetation); in this case, the authors measured the area where the substrates were collected. The authors also used a $10 \times 10 \mathrm{~cm}$ frame to collect the algae, taking into account the algae projective covering of the bottom section. The algae were preserved using formalin (4\%). The species composition was determined using microscopes Carl Zeiss Axio Scope A1 (1000'; Germany), MBS-10 (70'; Russia) and Mikmed-1 (400'; Russia), according to Russian and foreign algae identification guides (Gollerbakh et al., 1953; Vinogradova, 1980; Moshkova, 1986; Rundina, 1998). The species composition of higher aquatic plants was determined according to 'Flora of Siberia' (Kashina et al., 1988; Doron'kin et al., 1997; Timokhina et al., 1993). Herbarium samples are stored at the Institute of Natural Resources, Ecology, and Cryology (Siberian Branch of RAS).

In the process of classifying vegetation, the authors applied the dominant approach for determination of communities. Application of this approach makes it possible to reveal the leading role of plant dominants, especially edificators, in the processes of transformation of matter and energy in the community (Lavrenko, 1982). To distinguish the vegetation units, the authors used the principles of Shennikov (1935) applied in the classifications of Katanskaya (1981). 


\section{Results}

\section{Physical-geographical characteristics of the littoral}

According to the work by Shishkin (1973), Lake Arakhley is located in an area of extremely continental climate. Obyazov (2013) gave ambiguous assessment of the manifestations of climate warming. Thus, he wrote, 'on the one hand, the temperature of summer water is rising, the number of days, when water temperature is above $10^{\circ} \mathrm{C}$, is increasing, the duration of the period of ice phenomena is reducing, and the thickness of ice is decreasing. On the other hand, the facts show that water temperature falls below $4^{\circ} \mathrm{C}$ earlier, and the number of days, when the temperature is above $4^{\circ} \mathrm{C}$, is decreasing, the period of ice phenomena begins earlier, and the time, when the lake is frozen over, is becoming generally longer' (Obyazov, 2013, p. 49). According to the same author, the thickness of the ice cover fluctuated between 125 and $170 \mathrm{~cm}$ during the studied period.

Climatic periods with high precipitation (wet periods) lead to an increase in the water level of the lakes (1960-1965, 1969-1974, 1995-2002). These years are characterised as highwater years. The periods of low precipitation (dry periods) lead to a decrease in the water level of the lakes (1980-1983, 2014-2017). These years are characterised as low-water years. The period considered in the article (1998-2017) is characterised by a decrease in the water level of the lakes. The data on the change in the maximum depth of the lake are presented in Table 1. With a decrease in the depth of Lake Arakhley, transparency of water decreases, but its mineralisation remains unchanged (Table 1).

The littoral zone of Lake Arakhley is an exclusive area of distribution of rooted aquatic plants. It extends from the shoreline to the lower boundary of their growth. Shishkin studied Lake Arakhley during high-water period in the early 1960-s. According to habitat conditions of benthic animals, he distinguished the following zones in the lake. The first zone - up to the isobath of $7 \mathrm{~m}$ (the lower boundary of the Potamogeton zone) - was defined as the littoral. The second one- up to the isobath of $11 \mathrm{~m}$ (the lower boundary of Charales and mosses) was defined as the sublittoral. The last zone was the profundal. The author pointed out that with inter-annual changes in the level of lakes, the boundaries of the selected zones shifted (Shishkin, 1967). In the low-water year of 2017, the littoral boundary was at a depth of $5 \mathrm{~m}$.

The position of water level in summer is different in low-water and high-water years. And the level of lower ice edge in winter is also different (Fig. 2d). With a relatively equal

T a b l e 1. Morphometric and hydrochemical characteristics of the littoral of Lake Arakhley in low-water and highwater phases.

\begin{tabular}{|l|c|c|c|c|c|}
\hline \multirow{2}{*}{ Year } & \multicolumn{5}{|c|}{ Parameter } \\
\cline { 2 - 6 } & $\mathbf{S , \mathbf { ~ k m } ^ { \mathbf { 2 } }}$ & $\mathbf{D}, \mathbf{m a x} . \mathbf{~ m}$ & $\mathbf{k}$ & Transparency, $\mathbf{~}$ & TDS, $\mathbf{m g} / \mathbf{l}$ \\
\hline $1998-2000$ & 58.481 & 15.5 & 0.92 & $7.0-11.0$ & $115-150$ \\
\hline 2008 & 56.994 & 14.3 & 0.81 & $4.5-7.5$ & $153-167$ \\
\hline 2017 & 55.962 & 13.5 & 0.93 & $3.7-5.8$ & $131-167$ \\
\hline
\end{tabular}

Notes: D - depth; k - index of angularity of the coastline. 
thickness of ice (at a maximum of 150-170 cm),there was a great difference between low-water and high-water years in the width of the area of the littoral, affected by the lower surface of the ice cover. Thus, in the winter of 1999-2000, the width of this area was 50-60 m near Preobrazhenka village; in the winter of 2016-2017, its widthreached $150 \mathrm{~m}$ (Fig. 2). Thereby, at low-water level, when ice thickness reaches its maximum during the cold period, the ice cover occupies a significant part of the shallowzone of the littoral. At the same time, during the high-water period, almost entire shallowzone was submerged throughout the winter.

The length of the littoral in the high-water period was $380-400 \mathrm{~m}$. It consists of 30 $\mathrm{m}$ of the flooded shore, 270-300 $\mathrm{m}$ of the shallow zone and $90-110 \mathrm{~m}$ of the underwater slope. The higher values of bottom gradient are typical for the flooded shore $(0.5 \%)$ and for the underwater slope $(0.13 \%$ ). The bottom gradient of the shallow zone is $0.083 \%$. Figure 2 shows bottom profile of the littoral near Preobrazhenka village.

The peculiarities of the morphometric structure of the littoral in 2017 included the appearance of temporary water bodies on the dried part of the littoral. In spring and early summer period of 2017, groundwater discharge formed temporary water bodies on the transitional area between the flooded shore and the shallow zone. They had shape of narrow strips $(1.0-1.5 \mathrm{~m}$ ) with a depth of up to $10 \mathrm{~cm}$ (mainly $5 \mathrm{~cm}$ ). These water bodies were scattered and had no connection with each other. The number of such water bodies and their size were high in the shore areas near the gullies formed by runoff on the coastal slope. During the entire period of open water, additional temporary water bodies appeared in the splash zone because of the formation of sandbars from coastal sand and remnants of aquatic vegetation of the upper part of the littoral. The height of the sandbars determined the depth $(10-15 \mathrm{~cm})$ of these pools. Their area $\left(5-10 \mathrm{~m}^{2}\right)$ determined the gradient of the shore. A significant difference between the spring temporary water bodies and the temporary pools in the splash zone is that the latter remained connected to the mother lake because of periodic erosion of the sandbars.

The studies of the composition and distribution of soil particles in the littoral were carried out on the dried and submerged parts of the littoral. It was found that the largest gravel and pebble soil particles compose the highest parts of the littoral. These particles are the product of erosion of the coastal slope (Fig. 2b). The shallow zone is composed of sands; the size of sand grains naturally decreases with an increase in the depth of the zone. The study revealed high amount of fine-dispersed organic sediments in the sands of the shallow zone in the high-water period. The data on the distribution of soils on the lake profile in high-water and low-water years are presented in Fig. 2c.

Special studies of wave activity in the littoral of Lake Arakhley were not carried out. However, it is undoubtedly high and its effect on macrophytes in the littoral of the lake is significant. It is obvious that during the transition from a high-water period to a low-water period, with a change in depth for $2 \mathrm{~m}$, both the breaking zone and the area subjected to maximal wave influence moved towards the centre of the lake. According to the data on Lake Ladoga (Kurashov, 2011), the width of the breaking zone is limited by depths between the shoreline and the isobath, which is calculated as the maximum height of the storm wave increased 1.28 times. 


\section{Composition, spatial distribution, and dynamics of macrophytes}

In the studied period (1998-2017), the authors observed 21 taxa of macroscopic filamentous algae of three divisions (Cyanobacteria, 9; Chlorophyta, 7; Charophyta, 7) in the littoral of Lake Arakhley. Seven species of vascular plants were registered (Table 2). In general, macrophytic filamentous algae, cyanophytes and vascular plants are represented by cosmopolitan species that are widespread in the Palearctic. The rarely observed species include Aegagropila linnaei Kützing, Sirogonium sticticum (Smith) Kützing and Zygogonium ericetorum Kützing, which have specific requirements for habitats.

$\mathrm{T}$ a b l e 2. Composition of macrophyte taxa in the littoral of Lake Arakhley near Preobrazhenka village in 1999 (according to Bazarova, 2002; Kuklin, 2002) and in 2017.

\begin{tabular}{|c|c|c|}
\hline Taxon & 1999 & 2017 \\
\hline Nostoc pruniforme C. Agardh ex Bornet \& Flahault & ++ & ++ \\
\hline Nostoc kihlmanii Lemmermann & + & - \\
\hline Gloeotrichia pisum Thuret ex Bornet \& Flahault & + & +++ \\
\hline Tolypothrix distorta Kützing ex Bornet \& Flahault & +++ & + \\
\hline Tolypothrix distorta f. penicillata Kossinsk. & +++ & + \\
\hline Rivularia borealis P.G.Richter & ++ & - \\
\hline Calothrix fusca f. parva (Ercegovic) Poljansky & +++ & - \\
\hline Calothrix kossinskajae Poljansky & +++ & - \\
\hline Calothrix parietina Thuret ex Bornet \& Flahault & ++ & - \\
\hline Chaetophora elegans (Roth) C. Agardh & +++ & + \\
\hline Stigeoclonium farctum Berthold & +++ & - \\
\hline Stigeoclonium tenue (C. Agardh) Kützing & ++ & - \\
\hline Oedogonium sp. ster. & ++ & + \\
\hline Bulbochaete sp. ster. & + & - \\
\hline Cladophora fracta (O.F. Müller ex Vahl) Kützing & + & ++ \\
\hline Aegagropila linnaei Kützing & + & - \\
\hline Mougeotia sp.ster & + & - \\
\hline Spirogyra $\mathrm{sp}_{2}$ ster & + & + \\
\hline Sirogonium sticticum (Smith) Kützing & +++ & - \\
\hline Zygnema cruciatum (Vaucher) C. Agardh & + & - \\
\hline Zygogonium ericetorum Kützing & - & ++ \\
\hline Chara arcuatofolia Vilh. & ++ & + \\
\hline Nitella opaca L. & ++ & - \\
\hline Potamogeton perfoliatus L. & ++ & ++ \\
\hline Potamogeton compressus L. & + & - \\
\hline Potamogeton praelongus Wulf. & ++ & + \\
\hline Stuckenia pectinata (L.) Börner s.l. & + & ++ \\
\hline Myriophyllum sibiricum Kom. & + & ++ \\
\hline Ceratophyllum demersum L. & +++ & +++ \\
\hline Lemna trisulca L. & +++ & + \\
\hline
\end{tabular}

Notes: '+' - rare; '++' - common; '+++' - abundant. 


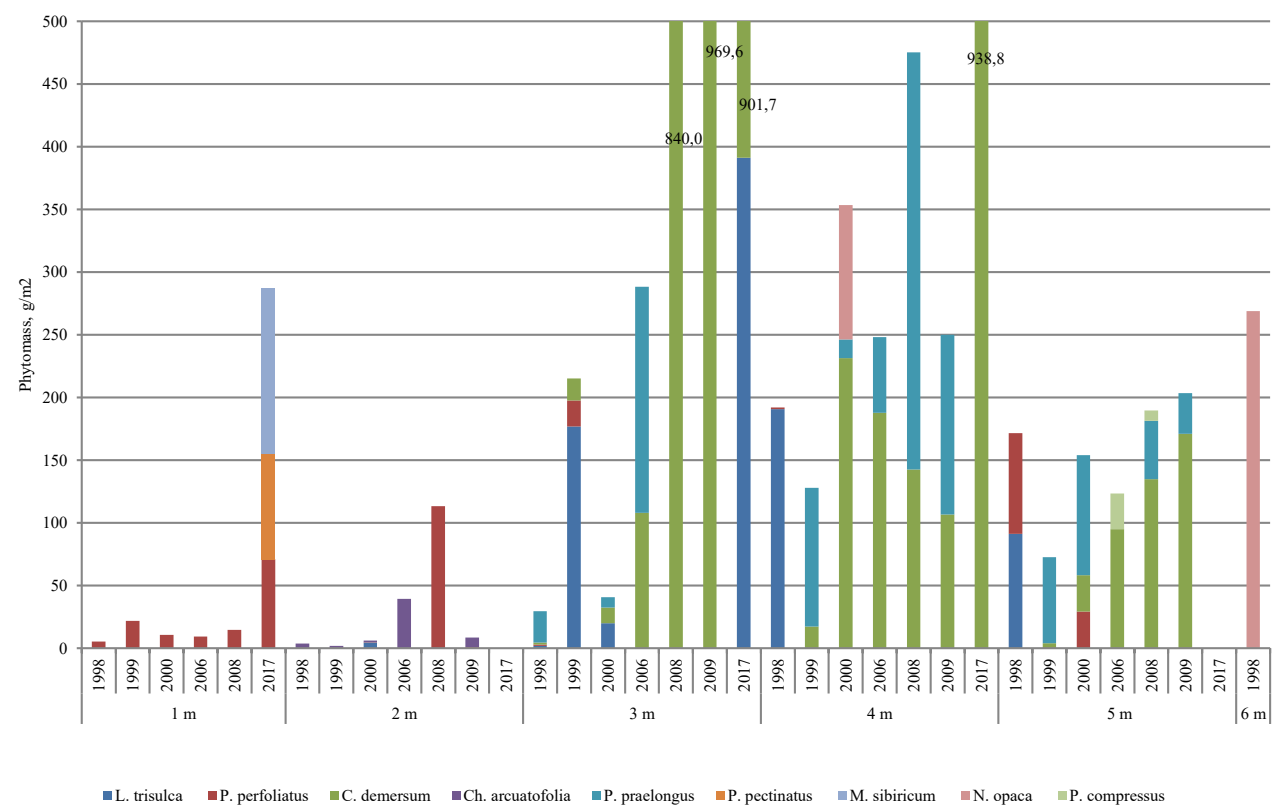

Fig. 3. Dynamics of hydrophyte phytomass distributed by absolute depth (Lake Arakhley near Preobrazhenka village).

In the high-water period of 1998-2000, vegetation of macrophytes in the littoral formed four ecological groups: epilithon, epiphyton, metaphyton and phytobenthos. In the epilithon, 14 species of macroalgae were identified, which were evenly distributed in the area adjacent to the shore. The most abundant vegetation on the territory from the shoreline to the $0.5 \mathrm{~m}$ isobath belonged to the rooted forms of the Rivulariaceae and Chaetophoraceae families. Seasonal changes in the species composition were manifested by the dominance of the Calothrix kossinskajae V. Poljansky during the summer period and its replacement by C. fusca f. parva (Erceg.) V. Poljansk in autumn. On some parts of the littoral in the epilithon, green alga Stigeoclonium tenue var. tenue (Ag.) Kütz grew and even dominated sometimes. In September, the number of Chaetophora elegans (Roth) Ag. increased. At a depth of less than $1.0 \mathrm{~m}$ in the metaphyton, Stigeoclonium sticticum $\mathrm{f}$. sticticum grew on the littoral areas that were free of higher aquatic plants. In 1998, the vegetation of the alga continued until the last decade of September. In 1999, it continued until August. The phytomass of the alga was $1.8 \mathrm{~g} / \mathrm{m}^{2}$. The amount of phytomass largely depended on the presence of dead parts and rhizomes of higher aquatic or flooded terrestrial plants, which the alga used as substrates.

The macroalgae of the epiphyton were studied on Lemna trisulca, Potamogeton praelongus, $P$. perfoliatus, Ceratophyllum demersum and Fontinalis sp. The most intense growth of algae on Potamogeton perfoliatus, Chara arcuatofolia and Lemna trisulca was registered on 
the depths of 1.0-2.5 m. Within the vegetation period, the maximum species diversity was observed at the end of July and the beginning of August; the maximum of quantitative development was observed at the end of August and the beginning of September. The greatest number of algae colonies grew on the dying stems of Potamogeton perfolia-

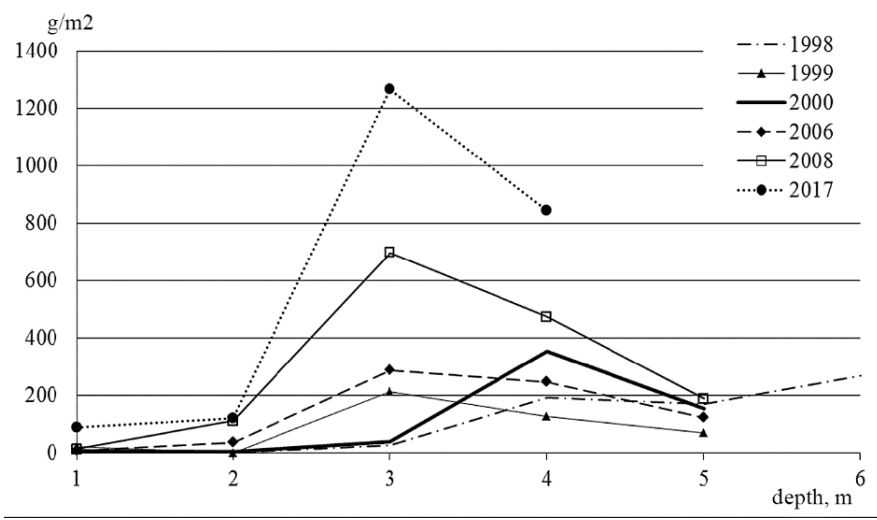

Fig. 4. Distributions of mean values of hydrophyte phytomass on the bottom profile of Lake Arakhley near Preobrazhenka village. tus. As the large colonies of Gloeotrichia natans and G. pisum were observed on Lemna trisulca in June, it was supposed that their single colonies could overwinter on the vegetation growing under the ice.

Vascular plants and charophytes dominated in phytobenthos, starting from the depths of $0.5-0.8 \mathrm{~m}$; their communities had clearly defined boundaries. The ecological series represented according to the depths of 1.0-2.0-3.0-4.0-5.0-6.0 m had the following sequence: Potamogeton perfoliatus (a) - Chara arcuatofolia (b) - Lemna trisulca (c) - Ceratophyllum demersum (d) - Potamogeton praelongus (e) - Nitella opaca. It was characterised by the following percentage ratio of phytomass: a: b: $c: d: e=14.2: 13.3: 29.0: 30.1: 13.4$. In 1998, the dense communities of N. opaca occupied maximal 6-m isobath. In 1999, the area of their distribution decreased sharply; they were represented by small clumps at $4-m$ depths. In 2000 , N. opaca communities were not found in this area (Fig. 3).

The study of macrophytes in the low-water period was carried out in the littoral of the lake and in temporary pools on its dried part; three ecological groups were studied: epiphyton, metaphyton and phytobenthos.

The composition of species in each of the spring temporary pools was determined by a complex of factors specific to particular water body. Amongst the species, small colonies of Nostoc pruniforme were noted, as well as Nostoc commune Vaucher ex Bornet \& Flahault. The latter is the soil alga widespread on the territory of the Transbaikal region. In early summer, flora of macroscopic algae of the splash pools was represented by cyanophytes (Gloeotrichia pisum, small colonies of Nostoc pruniforme). There were no filamentous (green and Charophyta) algae. By the end of summer, various filamentous forms appeared; their biomass reached $6.5-10.9 \mathrm{~g} / \mathrm{m}^{2}$ in wet weight. Along with filamentous forms, Chara arcuatofolia vegetated. Its phytomass was more than $250 \mathrm{~g} / \mathrm{m}^{2}$ in wet weight. Right before the lake froze over in autumn, vegetation of Cladophora fracta was noted amongst the aquatic plants in the splash pools and near the shoreline. Its phytomass reached $38 \mathrm{~g} / \mathrm{m}^{2}$ in wet weight. For the first time in the lake, Zygogonium ericetorum was registered. The alga grew on open areas of the splash pools with a depth of $1-3 \mathrm{~cm}$. Its phytomass reached $28 \mathrm{~g} / \mathrm{m}^{2}$ in wet weight. 


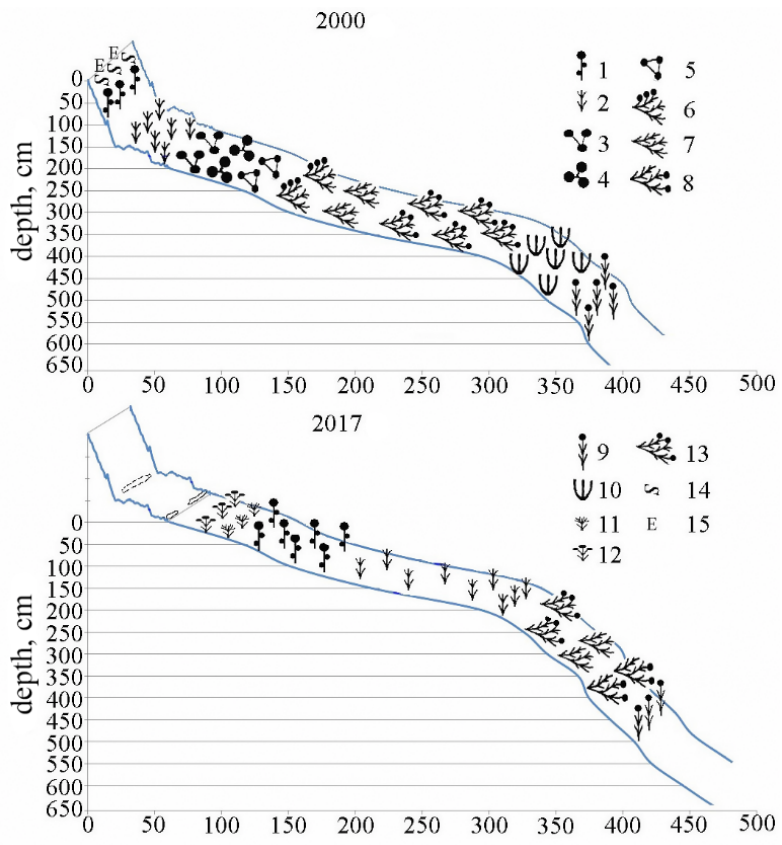

Fig. 5. Distribution of various types of vegetation in the littoral of Lake Arakhley near Preobrazhenka village. Associations: (1) Potamogeton perfoliatus; (2) Chara arcuatofolia; (3) Lemna trisulca-Potamogeton perfoliatus; (4) Lemna trisulca + Ceratophyllum demersum-Potamogeton perfoliatus; (5) Lemna trisulca + Ceratophyllum demersum-Potamogeton Ceratophyllum demersum; (8) Ceratophyllum demersum-Potamogeton praelongus; (9) Potamogeton praelongus; (10) Nitella opaca; (11) Myriophyllum spicatumum; (12) Potamogeton pectinatus; (13) Ceratophyllum demersum + Lemna trisulca-Potamogeton perfoliatus; (14) Sirogonium sticticum; (15) Chaetophora elegans. praelongus; (6) Ceratophyllum demersum-Potamogeton perfoliatus; (7)

Six species of macroalgae were registered in the epiphyton. They belonged to two divisions: Cyanobacteria (3) and Chlorophyta (3). Most of the plants growing in the area from the shoreline to the 5-m isobath were the rooted forms of the Rivulariaceae family. Gloeotrichia pisum was dominant. The composition of taxa is presented in Table 2. Nostoc pruniforme was the most 'noticeable' species in the metaphyton. In the phytobenthos, the dominant composition of hydrophytes did not change in the low-water period. However, the maximum depth of plant growth (measured from the water surface) reduced from 6.0 to $4.5 \mathrm{~m}$; the quantitative ratios of the dominant species also changed (Fig. 3). The communities of hydrophytes in the part of the littoral near Preobrazhenka village began to grow starting from the shoreline. Up to the depths of $0.5-0.8 \mathrm{~m}$, they were represented by well-developed communities of Potamogeton perfoliatus, $P$. pectinatus and Myriophyllum sibiricum. The values of their phytomasses are presented in Figures 3 and 4. At the depths of 1.5-2.0 m, the communities of Chara arcuatofolia grew as they did before. Ceratophyllum demersum communities occupied more deep zones of the littoral. At the depths of $3.0 \mathrm{~m}$, the groups of Lemna trisulca were found in the hollows of the bottom relief. Potamogeton praelongus was registered at the depths of 4.0-4.5 m.

\section{Discussion}

The lower boundary of the littoral in freshwater reservoirs is the greatest depth of distribution of aquatic plants (Raspopov, 1975). In the absence of macrophytes, the lower boundary of the littoral zone is determined by the lower boundary of the trophogenic layer, that is, by 
transparency of water (Ruttner, 1962). In the littoral of Lake Arakhley, both these boundaries remained almost unchanged in high-water and low-water periods. In 2017, the level of the shore line corresponded to the depth of $2 \mathrm{~m}$ in 1998-2000 (Fig. 2d). However, the maximum depth of plant growth in $2017(4.5 \mathrm{~m})$ was only $50 \mathrm{~cm}$ deeper than that observed in 1998-2000. In the period from 1998 to 2017, there was a change in the boundaries of the littoral in the dried upper part of the lake; the lower boundary moved for 50-70 m towards the centre of the lake.

In the low-water period, the dried part of the littoral is a shore. Thus, it is related only in an indirect manner to the habitat of macrophytes of littoral. However, the splash zone of most Eurasian lakes is very poorly studied or not studied at all (Timoshkin et al., 2012). The study of macrophytes in the spring temporary pools and in pools of the splash zone revealed a high degree of similarity in composition of macroscopic algae of these water bodies and the main lake. Communities of Chara arcuatofolia grew both in the splash pools and at the depths of 1.5-2.0 m on sandy soils of the main lake. According to the literary data, the spores of charophytes can persist for several years in the layer $(1-7 \mathrm{~cm})$ of bottom sediments; under favourable conditions, they can grow again (Ozimek, 2006). The ability of spores of charophytes to remain viable for several years is evidenced by their appearance in the pools of the lakeside area. At the same time, the splash pools are a new environment inhabited by species that were not observed in the main lake (e.g. Zygogonium ericetorum).

High insolation, transparent crystalline ice and dry winters contributed to the formation of favourable conditions for subglacial vegetation of phytoplankton and a number of macrophyte species, for example, Chara arcuatofolia, Lemna trisulca and Ceratophyllum demersum. These factors also contributed to the reduction of harsh midwinter period to 2-3 months and the activation of spring growth processes and reproduction of organisms under the ice. On the basis of the peculiarities of the hydrobiological regime that formed in the reservoirs of Transbaikal region, Shishkin distinguished the Transbaikal-Mongolian limnic country (Shishkin, 1973). The processes described above were also noted in the high-water period of 1999-2000, when practically the entire shallow zone was flooded throughout the winter period, which also promoted subglacial vegetation of plants. The studies carried out in the low-water period with high snow cover of the ice showed that the heating of the subglacial waters started only after the melting of the snow cover. These studies also demonstratedthat the ice lying on the shoreline prevented the subglacial vegetation of the plants. During the period of ice breaking, the upper littoral was intensively ploughed, which also inhibited the development of the variety of rooting plants.

Vegetation of macroalgae in epilithon in the high-water period was possible because of the presence of pebbles in the composition of the soil (Fig. 2). Owing to the decrease in the water level in 2017, the shoreline near the village Preobrazhenka moved for $50 \mathrm{~m}$ towards the centre of the lake. Consequently, the zone with sand-gravel sediments disappeared from the submerged part of littoral. Owing to the absence of a fraction of gravel and pebbles on the shoreline, the epilithon community did not develop; a reduction in the qualitative composition of macroscopic algae (from 20 to 9 species) was observed. At the same time, in the area from the shoreline to the depths of $0.5-0.8 \mathrm{~m}$, the diversity of hydrophyte communities increased (Potamogeton perfoliatus, P. pectinatus, Myriophyllum sibiricum). The increase in 
amount of organic fine-dispersed sediments in the sands of the shallow zone in the highwater period is a result of high density of plants, which retained the silt there. Mass development of communities of M. sibiricum and Cladophora fracta indicated that eutrophy of the upper littoral increased.

The diversity of aquatic vegetation in the upper part of the littoral (from the shoreline to the depth of $1.5 \mathrm{~m}$ ) promoted the development of the epiphyton. The most 'noticeable' species in the metaphyton were species such as Nostoc pruniforme, Aegagropila linnaei and Stigeoclonium sticticum. The latter species used dead remains of aquatic and flooded terrestrial plants for the formation of cotton-like clusters. In general, the number of species of macroepiphytic algae increased with an increase in depth. However, the number of algal colonies on higher aquatic vegetation declined sharply (Kuklin, 2002). Cyanobacteria predominated on submerged vegetation in shallow waters; with an increase in depth, the proportion of green algae increased. In 2017, there were no significant changes in the species composition of the epiphyton during the summer-autumn period.

Communities of Ceratophyllum demersum were greatly developed in the low-water period of 2017 at the depths of more than $2 \mathrm{~m}$ (Fig. 5). In comparison with 1998-2000, the role of Lemna trisulca and Potamogeton praelongus decreased. Plant associations with predominance of Ceratophyllum demersum occupied equal depths in low-water and high-water years. However, owing to the lowering of the water level, they moved deeper into the lake to the places where the association of Nostoc opaca had previously grown. Presumably, this was the reason that caused the reduction of the areas inhabited by N. opaca.

Both high-water and low-water periods are characterised by specific sets of conditions for the development of macrophytes in the littoral of the lake. A characteristic feature of the high-water period is the abrasion of the flooded coastal area. On the shoreline, the sandbars are formed from plant remains and sand. A significant gradient of the bottom prevents the formation of the splash pools. During the studied period, a decrease in the water level by $150 \mathrm{~cm}$ led to the displacement of the shorelinefor a distance of $20 \mathrm{~m}$. The low-water period (from 2008 to the present) is characterised by erosion of the shallow zone and, because of a small gradient, formationof the splashwaterbodies above the shoreline. During this period,a decrease in the water level by $50 \mathrm{~cm}$ led to the displacement of the shoreline for a distance of $40 \mathrm{~m}$ (Fig. 2). Appearance of the splash poolsled to the appearance and development of species of macroscopic algae that previously were not observed in the littoral of the lake.

According to the analysis of the data on the composition and distribution of macrophytes in the littoral of Lake Arachley in the period from 2000 to 2017, there are two types of development of the littoral vegetation. In the high-water period, the higher aquatic vegetation is combined with the fields of charophytes, as well as with macroscopic algae of epilithon, epiphyton and metaphyton. The authors of the article proposed to call this type of vegetation development the 'mixed' one. A significant contribution to the biogenic nutrition of vegetationis provided, along with the supply from the drainage basin, by the organic matter accumulated during the low-water period and deposited in sandbars. By the end of winter, ice cover occupies less than $20 \%$ of the territory available for growth of algae. This leads to subglacial vegetation of charophytes, duckweed and so onand, consequently, to development of variety of epiphytes. 
In the low-water period, the higher aquatic vegetation dominates in the littoral. The authors proposed to call this type of vegetationdevelopment the 'grassy' one. The absence of stone substrates contributes to intensive vegetation of vascular plants and filamentous algae. This process is also promoted by biogenic nutrition coming both from the central part of the lake in the form of silt sediments and from the splash pools in the form of decomposed organic matter. By the end of winter, the ice cover occupies half of the territory available for growth of algae, which inhibits vegetation of perennial plants.

\section{Conclusion}

The results of the studies show that it is necessary to perform long-term series of observations to detect changes in the vegetation of littorals of lakes. The authors of the article determined the factors (such as the position of shoreline and of lower edge of the ice cover and changes in the fractional composition of bottom sediments and in bottom morphology) that affect dynamics of vegetation in the littoral of a dimictic water body in conditions of extremely continental climate. Short-term series of observations do not give enough data to figure out the true reasons for the noted changes. In the low-water and high-water periods, the composition and distribution of macrophytes differ. For high-water years, a 'mixed' type of growth of macrophytes in the littoral is typical; this type is characterised by belt spread of vascular plants combined with the belts of charophytes and filamentous algae in the epilithon. In the low-water period, vascular plants predominate in the littoral. This type of growth of macrophytes in the littoral is called 'grassy'. In spring, temporary water bodies appear on the dried part of the littoral. Another temporary water bodies are formed in the splash zone. The species composition of these water bodies is determined by the spores buried in the bottom sediments. Long-term observations of the composition and distribution of vegetation in the littoral allowed the authors to determine the possible depth of distribution of macrophytes in the lake, thereby establishing the lower boundary of the littoral of the water body. The obtained data will make it possible in the future to predict the dynamics of plant communities, taking into account fluctuations of water regime.

\section{Acknowledgements}

The authors are grateful to P.V. Matafonov for his help in collecting the material. The work was carried out within the framework of the project IX.137.1.3: Biodiversity of natural and natural-technogenic ecosystems of the Transbaikal region (Central Asia) as an indicator of the dynamics of regional climate change.

\section{References}

Atapaththu, K.S.S., Asaeda, T., Yamamuro, M. \& Kamiya H. (2017). Effects of water turbulence on plant, sediment and water quality in reed (Phragmites australis) community. Ekológia (Bratislava), 36(1), 1-9. DOI: 10.1515/eko-2017-0001.

Bazarova, B.B. \& Itigilova M.Ts. (2006.) Long-term production dynamics of aquatic vegetation in the Arakhley lake (Eastern Transbaikalia) (in Russian). Biology Bulletin, 33(1), 68-72. DOI: 10.1134/S1062359006010109.

Bekman, M.Yu. \& Gorlachev V.P. (1981). Biological productivity of Lake Arakhley (Transbaikalia) (in Russian). Novosibirsk: Nauka.

Bondareva, E.I. (1974). Primary production and destruction of organic matter of Ivano-Arakhley lakes (Transbaikalia) (in Russian). PhD dissertation, Irkutsk. 
Bykova, O.G. (2013). Ecology of coastal-aquatic biogeocenoses of the lakes of the Chanovsky system (in Russian). Interexpo Geo-Siberia, 4(2), 179-184.

Doron'kin, V.M., Kovtonyuk, N.K. \& Zueva V.V. (1997). Flora of Siberia. Vol. 11: Pyrolaceae - Lamiaceae (Labiatae) (in Russian). Novosibirsk: Nauka.

Dulepova, B.I. (1980). Rare, endangered, and valuable species of the flora of the Eastern Transbaikalia, which require protection (in Russian). In Flora, vegetation, and plant resources of Transbaikalia (pp. 3-9). Irkutsk: Irkutsk State Pedagogical Institute.

Gollerbakh, M.M., Kosinskaja, E.K. \& Polanskii V.I. (1953). Identification guide of freshwater algae of the USSR. Bluegreen algae. Vol. 2. Cyanophyta (in Rusian). Moscow: Nauka.

Ivanov, A.V. (1977). The Torey lakes. Hydrochemistry of rivers and lakes in extremely continental climate (in Russian). Vladivostok.

Kachaeva, M.I. (1974). Phytoplankton and phytobenthos of the Ingoda river (Transbaikalia) (in Rusian). PhD dissertation. Tomsk.

Kashina, L.I., Krasnoborov, I.M. \& Shaulo D.N. (1988). Flora of Siberia.Vol. 1: Lycopodiaceae - Hydrocharitaceae (in Russian). Novosibirsk: Nauka.

Katanskaya, V.M. (1981). Higher water vegetation of continental water bodies of the USSR. Methods of study (in Russian). Leningrad: Nauka.

Kozhov, M.M. (1950). Fresh waters of Eastern Siberia (the basin of Baikal, Angara, Vitim, the upper part of the Lena and the Nizhnyaya Tunguska) (in Russian). Irkutsk: Irkutsk Regional State Publishing House.

Kuklin, A.P. (2002). Phytoplankton, biofouling algae and primary production of organic matter (in Russian). In Ivano-Arakhleisky reserve: natural resource potential of the territories (pp. 80-84). Chita: Poisk.

Kuklin, A.P. \& Enikeev F.I. (2017). Aegagropila linnaei in lakes Arahley and Arey (Eastern Transbaikalia) (in Russian). European Journal of Natural History, 3, 19-20.

Kurashov, E.A. (2011). Littoral zone of Lake Ladoga (in Russian). Saint Petersburg: Nestor-Istoria.

Lavrenko, E.M. (1982). Plant communities and their classification (in Russian). Botanicheskiy Zhurnal, 67(5), 572-580.

Mikheeva, T.M. \& Lukyanova E.V. (2006). Direction and character of long-term changes in the phytocoenotic structure and indices of quantitative development of phytoplankton communities of the Narochansk lakes in the course of the evolution of their trophic status (in Russian).Izvestia of Samara Scientific Center of the Russian Academy of Sciences, 8(1), 125-140.

Moshkova, N.A. (1986). Identification guide of freshwater algae of the USSR (in Russian). Ulvophyceae class. Vol. 10. Leningrad: Nauka.

Obyazov, V.A. (2013). Dynamics of climatic and hydrological parameters. In N.M. Pronin (Ed.), The Ivano-Arakhley lakes at the turn of the century (state and dynamics) (pp. 42-51) (in Russian). Novosibirsk: Siberian Branch of RAS.

Ozimek, T. (2006). The possibility of submerged macrophyte recovery from a propagule bank in the eutrophic Lake Mikolajskie (North Poland). Hydrobiologia, 570, 127-131. DOI: 10.1007/s10750-006-0171-7.

Raspopov, I.M. (1975). Littoral zone of Lake Onega. General concepts (in Russian). In Littoral zone of Lake Onega (pp. 7-14). Leningrad: Nauka.

Raspopov, I.M., Andronnikova, I.N., Slepukhina, T.D., Raspletina, G.F., Rychkova, M.A., Barbashova, M.A., Dotsenko, O.N. \& Protopopova E.V. (1998). Coastal-aquatic ecotones of large lakes (in Russian). Saint Petersburg.

RosHydroMet (2014). Risks and benefits of the global climate change for the Russian Federation (in Russian). Federal Service for Hydrometeorology and Environmental Monitoring of Russia. http://www.meteorf.ru/press/ releases/8435/?sphrase_id=176244.

Rundina, L.A. (1998). Zygnematales of Russia (in Russian). Saint Petersburg: Nauka.

Ruttner, F. (1962). Grundriss der Limnologie. Berlin.

Scheffer, M. (1997). Ecology of Shallow Lakes. Population and Community Biology Series. Vol. 22. Springer Science \& Business Media.

Shapovalova, I.M. \& Vologdin M.P. (1973). On the quantitative account of Gammarus lacustris. Hydrobiological Journal, 9(5), 85-90.

Shennikov, A.P. (1935). Principles of classification of meadows (in Russian). Sovetskaya Botanika, 5, 35-39.

Shishkin, B.A. (1967). Seasonal dynamics of the macrobenthos biomass of the main lakes of the Ivano-Arakhley system. Uchenyye Zapiski Irkutskogo Gosudarstvennogo Pedagogicheskogo Instituta (Series: Biology), 24 (Part 1), 40-50.

Shishkin, B.A. (1973). Seasonal and annual variations in biological regime of lakes in an ultracontinental climate (Trans-Baikal Region of U.S.S.R) by Trans-Baikal Complex Expedition, Siberia. Hydrobiologia, 43(1-2), 253-261. DOI: 10.1007/BF00014270. 
Sirakov, I. \& Slavcheva-Sirakova D. (2015). The influence of climate changes on the hydrobionts: a review. Journal of Biodiversity and Environmental Sciences, 6(3), 315-329. http://www.innspub.net

Talovskaya, V.S. (1977). On the hydrological characteristics of the lakes of the Western part of the Chara basin. In Hydrochemistry of rivers and lakes in extremely continental climate (pp. 29-39). Vladivostok.

Timokhina, S.A., Frizen, N.V. \& Vlasova N.V. (1993). Flora of Siberia.Vol. 6: Portulaceae-Ranunculaceae. Novosibirsk: Nauka.

Timoshkin, O.A., Suturin, A.N., Bondarenko, N.A., Kulikova, N.N., Rozhkova, N.A., Sheveleva, N.G., Obolkina, L.A., Domischeva, V.M., Zaytseva, E.P., Malnik, V.V., Maksimova, N.V., Nepokrytykh, A.V., Shirokaya, A.A., Lukhnev, A.G., Popova, O.V., Potapskaya, N.V., Vishnyakov, V.S., Volkova, E.A., Zvereva, J.M. \& Logacheva N.F. (2012). Biology of the coastal zone of Lake Baikal. 1. Overview of the current knowledge on the splash zone, first results of interdisciplinary investigations, monitoring as a basic tool in ecological research. The Bulletin of Irkutsk State University (Series: Biology, Ecology), 5(3), 33-46.

Vinogradova, K.L. (1980). Identification guide of freshwater algae of the USSR. Green, red, and brown algae. Vol. 13. Leningrad: Nauka.

Vladimirova, Z.F. \& Dulepova B.I. (1966). Species composition of aquatic vegetation of the Ivano-Arakhley lakes. InVoprosy geografi i biologii (pp. 205-208). Chita: Chita Pedagogical Institute.

Vladimirova, Z.F. (1970a). On the issue of productivity of plant communities of lakes of the Ivano-Arakhley system. In Flora, vegetation, and plant resources of Transbaikalia (pp. 38-40). Chita.

Vladimirova, Z.F. (1970b). Some peculiarities of the vegetation growth of the lakes of the Ivano-Arakhley system. In Flora, vegetation, and plant resources of Transbaikalia (pp. 37-38). Chita.

Zębek, E. (2014). Succession of periphyton and phytoplankton assemblages in years with varying amounts of precipitation in a shallow urban lake (Lake Jeziorak Mały, Poland). Ekológia (Bratislava), 33(3), 259-273. DOI: 10.2478/eko-2014-0025.

Zolotareva, L.N. (1981). The higher aquatic vegetation of Lake Arakhley. In Biological productivity of Lake Arakhley (Transbaikalia). Novosibirsk: Nauka (Siberian Branch). 